\title{
Phylogenetic Analysis of ORF Virus from Goats in Tanzania: Short Communication
}

\author{
Julius J. Mwanandota ${ }^{1, *}$, Mercy Macharia ${ }^{2}$, Mpelumbe-Ngeleja C. A. R. ${ }^{1}$, Raphael Sallu ${ }^{1}$, Mmeta Yongolo ${ }^{1}$, \\ Timothy A. Holton ${ }^{2}$ \\ ${ }^{1}$ Tanzania Veterinary Laboratory Agency, Tanzania \\ ${ }^{2}$ International Livestock Research Institute (BecA-ILRI Hub), Kenya
}

Copyright $\mathrm{O} 2016$ by authors, all rights reserved. Authors agree that this article remains permanently open access under the terms of the Creative Commons Attribution License 4.0 International License

\begin{abstract}
ORF virus is a double-stranded DNA virus belonging to the genus Parapoxvirus (PPV) in the family poxviridae. ORF virus is the causative agent of contagious pustular dermatitis which is a zoonotic and neglected disease of humans and small ruminants. It causes severe exanthematous dermatitis that afflicts domestic and small wild ruminants. Cases of ORFV infections in goats in Tanzania have been reported for many years. The basis of reporting ORFV cases were mainly on clinical signs with no confirmatory tests (Ministry of Livestock Development reports-Tanzania). In this study, a case of proliferative dermatitis in goats was confirmed using PCR. A physical examination of the animal was carried out and tissue scrapings were collected for molecular analysis in the laboratory. The presence of ORFV in tissue scrapings from the lips was tested by GIF/IL-2gene polymerase chain reaction (PCR), DNA sequencing and phylogenetic analysis of the GIF/IL-2 gene. The results of this study indicated that the disease was caused by infection with a virus which is closely and genetically related to several ORF virus found in the data base. This is the first report to provide phylogenetic information about the ORF virus in Tanzania, which will be useful in prospective public health studies.
\end{abstract}

Keywords ORF Virus, PCR and Phylogenetic Analysis

\section{Introduction}

The ORF virus (ORFV) is the first member of the genus Parapoxvirus (PPV) genus and is a causative agent of contagious ecthyma in goats, sheep and other ruminants worldwide. The PPV genus includes bovine popular stomatitis virus (BPSV), pseudocowpox virus (PCPV) and PPV of red deer in New Zealand (PVNZ) (Fauquet et al., 2005; McInnes et al., 2006). Clinical signs of the disease range from contagious pustular dermatitis to formation of scabs in mucous membrane of the oral cavity, tongue, lips and teats of affected animals. Clinical signs of the disease in sheep and goat can be seen on the mouth as shown on Figure 1. The virus usually enters the host through damaged skin leading to scabs typically observed at the site of infection.
ORFV infects sheep and goats of all ages. During outbreaks, morbidity can approach $100 \%$, whilst mortality is usually less than $1 \%$. However, mortality can increase by $20 \%$ to $50 \%$ as a result of secondary complications such as stress, immunosuppression or concomitant disease and can exceed $90 \%$ in the case of 'malignant orf' (Scagliarini A et al., 2012). The disease is spread either by direct contact or indirectly via environmental contamination. (Klein and Tryland, 2005). The shed scabs contain high titres of stable virus, which if kept dry, can remain infectious long enough to sustain annual outbreaks of the disease. Severe outbreaks of ORFV can occur in naive flocks or herds, in which lesions are extensive and proliferative and do not spontaneously regress (Zhang et al., 2010). In young, stressed, or immunosuppressed sheep and goat, formation of severe bloody lesions can be fatal (Nitsche et al., 2005). The diagnosis is generally done on the basis of clinical signs, which are typical, but can be confused with symptoms of other vesicular diseases of sheep and goats - including foot and mouth disease (Watson 2004), bluetongue (Baipoledi, Nyange \& Hyera 2002), peste des petits ruminants (Rossiter \& Taylor 1994) and sheep and goat pox (Kitching 2004; Zheng et al., 2007). Other diseases that resemble ORFV include papillomatosis (Smith et al., 2002) and bacterial diseases such as staphylococcal dermatitis and dermatophilosis (Bath et al. 2011; Kitching 2004; Smith et al. 2002). Rapid and accurate differential diagnosis is therefore essential (McElroy \& Bassett 2007; Watson 2004). ORFV is a neglected disease which is zoonotic and an occupational hazard (Lederman et al. 2007; Steinhart 2005). ORFV in humans was first described clinically in 1934 (Newsome and Cross, 1934). The transmission of infection among individuals (and from animals to humans) is by direct or indirect contact with infected materials, and has been reported to be associated in adults involved in slaughtering of farm animals and in children visiting zoos and livestock fairs (Bayindir et al., 2011). The disease in human is characterised by a solitary skin lesion, which may follow an atypical course, such as lymphangitis, resembling a bacterial infection or neoplasm (Coskun et al., 2008, Karakas et al., 2010, MMWR, 2012). 

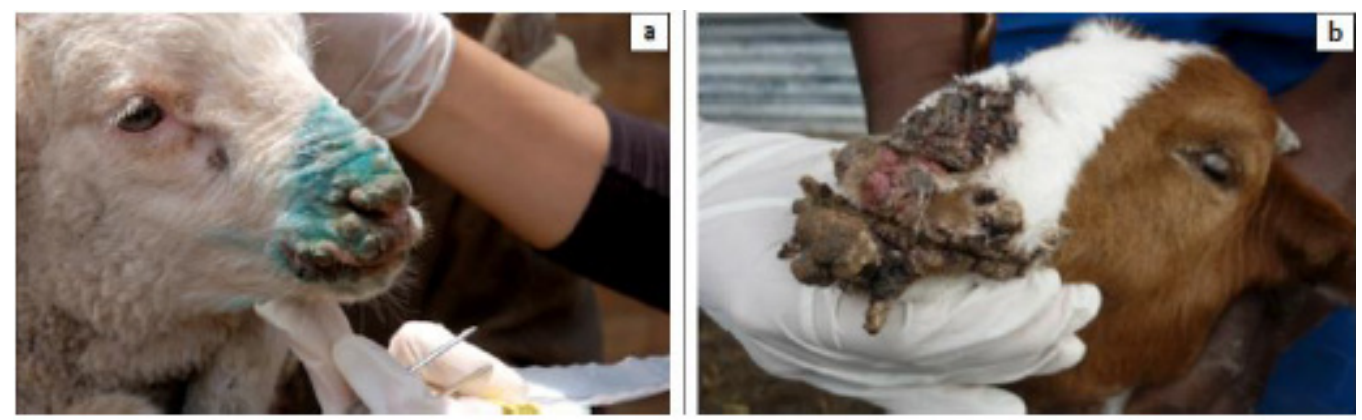

Figure 1. Typical clinical case of OV infection in sheep (b) proliferative orf lesion in boer goat (picture by Scagliarini et al., 2012)

\section{Case Presentation}

The outbreak reported in this case study originated from goat stalls of two households in Kyela district of Tanzania. On $1^{\text {st }}$ March 2013, a research team from Tanzania veterinary Laboratory Agency (TVLA) visited Kyela district for transboundary animal diseases surveillance. During the visit a typical clinical case of ORFV was detected in goats which had been brought from Malawi. Affected goats showed nodular lesions on the lips, and around the mouth. Other animals had large scabs noticed as verrucose mass. The lesions were localised around the mouth region with typical features, which narrowed the clinical diagnosis to a few possible diseases such as ulcerative dermatosis and contagious ecthyma (Aiello, S.E. et al., 1998). Further investigation was done in the laboratory to analyse the collected samples.

\section{Methodology}

\section{Sample Collection}

Tissue samples were collected from affected goats by taking the nodular lesion and scabs around the mouth. These samples were stored in a cool box loaded with ice pack and transported to Tanzania veterinary Laboratory Agency (TVLA) headquarters (in Das es salaam) and stored at $-80^{\circ} \mathrm{C}$ for further processing.

\section{Sample Processing and DNA Extraction}

DNA was extracted from tissue scrapings using a Genomic DNA Purification Kit (Invitrogen) using the manufacturer's protocol.

\section{Polymerase Chain Reaction}

ORFV-specific primer used was from granulocycyte macrophage colony stimulating factor inhibitory factor or interleukin -2 (GIF/IL-2) gene. The latter gene is the virulence factor found only in Parapox viruses (GIF gene accession number AF192803) Deane et al., 2000 and Ramesh et al., 2008. The primer sequences used for amplification of partial GIF/IL-2 gene were: Forward primer: 5'-gctctaggaaagatggcgtg-3', Reverse primer: 5'-gtactcctggetgaagagcg-3'. The primers were synthesized and supplied by Bioneer Inc. The PCR mix consisted of DNA template $5.452 \mathrm{ng} / \mu \mathrm{l} ; 0.02 \mu \mathrm{M}$ Forward primer $-1 \mu \mathrm{l}$;
$0.02 \mu \mathrm{M}$ Reverse primer $-1 \mu \mathrm{l}$, Ultra purified water $-17 \mu \mathrm{l}$ and bioneer Accupower TaqPCR Premix ${ }^{\mathrm{TM}}$ with total reaction mix of $20 \mu \mathrm{l}$. The PCR mixture was then subjected to the following PCR cycling conditions using a thermal cycler machine (Applied biosystems). Initial denaturation at $94^{\circ} \mathrm{C}$ was repeated for 5 minutes followed by second denaturation at $94^{\circ} \mathrm{C}$ for 30 seconds annealing at $57^{\circ} \mathrm{C}$ for 1 minute and initial extension at $72^{\circ} \mathrm{C}$ for 1 minute. Second denaturation, annealing and initial extension were repeated for 30 cycles followed by a final extension of $72^{\circ} \mathrm{C}$ for 10 minutes. The sample was diluted from $545.2 \mathrm{ng} / \mu \mathrm{l}$ to $5.452 \mathrm{ng} / \mu \mathrm{l}$ to obtain the expected band of 408 base pair.

\section{Analysis of PCR Amplification Products (amplicons)}

Three microliters $(3 \mu \mathrm{l})$ of PCR products from each sample were separated electrophoretically in $2 \%$ agarose gel (Gelrose TM, Sigma life science) containing $0.5 \mu \mathrm{g} / \mathrm{ml}$ of Gel red running for 45 minutes at a voltage of $100 \mathrm{~V}$ (Sambrook and Russell, 2000). 1kb plus DNA marker was used to ascertain a predicted amplicon size of 408 base pair. Results were recorded by gel documentation system (Ultra Violet Product Bio imaging system United Kingdom).

\section{Sequencing and Data Analysis}

The PCR amplicons of the predicted size (about 408 bp) for Orf virus were purified using genjet gel extraction kit and sequenced using Sanger sequencing at Segolip unit platform. The sequences data were cleaned and aligned by using CLC main workbench version 7 software (CLC manual 2014). Comparison of orf suspected sample sequences with those available in the GenBank database was performed using the online BLAST programs. A phylogenetic tree was constructed by using MEGA version 6.0. In MEGA version 6 the statistical method used was maximum likelihood with 1000 bootstrap replicates using (Tamura, K. et al., 2013). The sequence was letter submitted to National Center for Biotechnology Information (NCBI) using BankIt for requesting gene bank Accession number.

\section{Results}

\section{PCR}

Four technical replicates of DNA samples amplified were shown to have band size of approximately $400 \mathrm{bp}$ as shown on Figure2. 


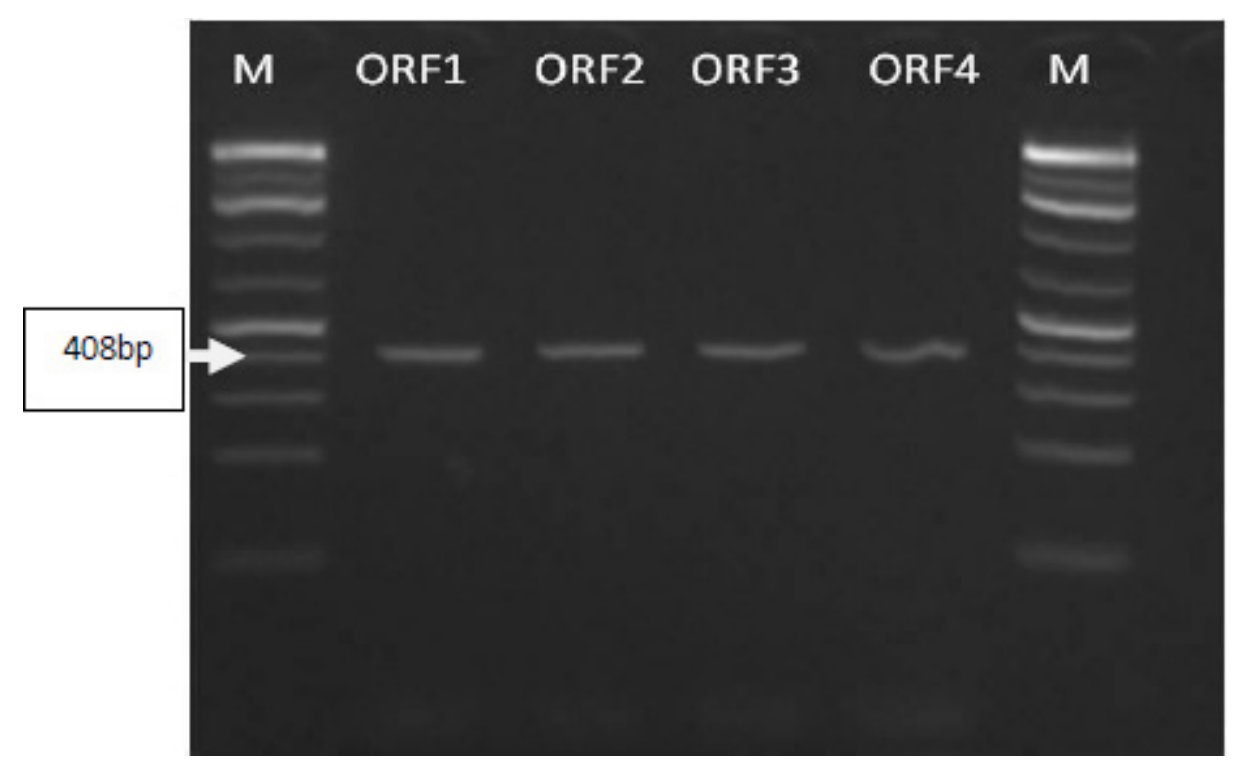

Figure 2. Gel picture of ORFV sample replicates ORF1, ORF2, ORF3, ORF4 are the technical replicates while M is the $1 \mathrm{~kb}$ plus ladder used.

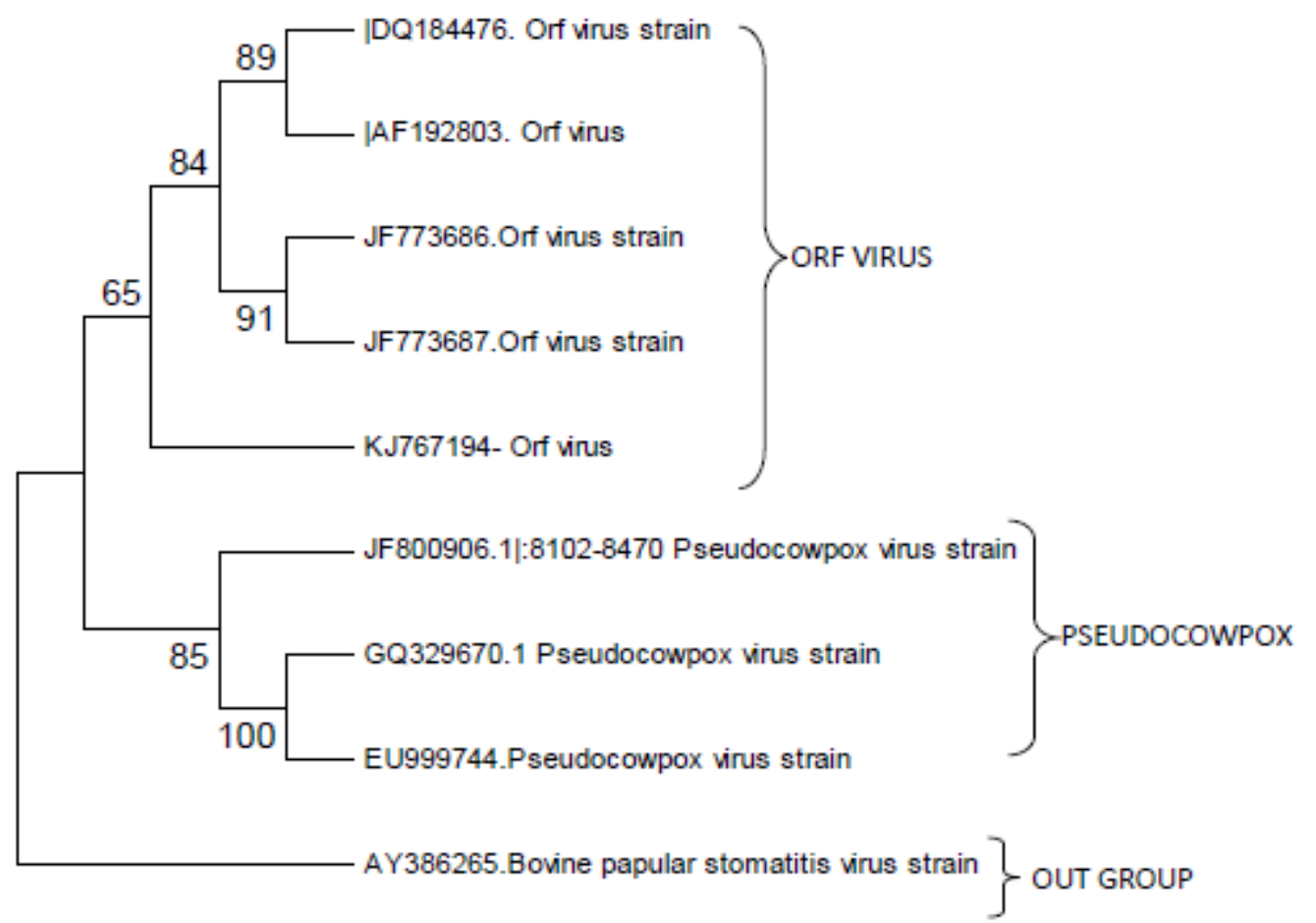

Figure 3. Phylogenetic tree of Parapox virus (PPV) and Capripox viruses (CaPV) with Orf virus sample from Kyela District with other orf virus from data base

\section{Phylogenetic analysis}

Interrogation of sequence data in the NCBI produce related sequence which were used in the production of a phylogenetic tree as seen on figure 3. The tree was constructed using maximum likelihood statistics where boostrap value was computed at maximum cut off point of $60 \%$. In the later tree a capripox virus was incorporated in the tree as outgroup. The orf virus suspected sample sequence was submitted to the NCBI through BankIT and given gene bank accession number of KJ767194.

\section{Discussion and Conclusions}

Clinical signs in the goats observed in this case study are similar to previous case reports of orf (Scagliarini A et al., 2012, Baipoledi et al 2002). Presence of lesions in the epidermis of the muzzle and lips without visible lesions on other body parts on this case study imply its low severity whereas higher severity the lesion extends to molar area of the maxilla or on the rumen mucosa as well as other parts of the body (Bouznach, A., 2013)

PCR results and Clinical signs observed differentiate this 
case from other related diseases like blue tongue, ulcerative dermatosis and benign tumors Baipoledi et al 2002. The choice of GIF/IL-2 as target gene bases on the fact that it is novel cytokine inhibitory protein encoded by several strains of the parapoxvirus Dean D et al 2000. The letter entails its detection capacity of PCR on parapox viruses as seen on the gel picture in Figure 2. Ramesh et al., 2008

Orf strain and pseudocowpox strain isolates were clustered different in the phylogenetic tree to form two groups of parapox virus. Two groups of sequence data as in the figure 3 have explained the phyogenetic relationship between KJ767194 and those in the NCBI. A high value of bootstrap (80-91\%) between the orf strains from NCBI data base suggest strong evidence that the sequences are clustered together more than KJ767194. Low bootstrap value (65\%) of KJ767194 suggests decrease in its relationship with sequence data from NCBI. Bovine popular stomatitis was used as an out group to identify the root of the tree in which both of the sequences belong to the Parapox virus genus.

We concluded that ORFV involved in this case study was closely related to other ORFV sequences deposited in the National Center for Biotechnology Information (NCBI). This is the first report to provide DNA sequence information and phylogenetic analysis of ORFV in Tanzania, which will be useful in prospective public health studies.

\section{Acknowledgements}

This work has been made possible by ILRI-BecA Hub and African Bioscience Challenge fund for supporting laboratory work, Tanzania Veterinary Laboratory Agency for sample collection and processing, Kyela District veterinary office for field sample collection and International Atomic Energy Agency for conceptual support.

\section{REFERENCES}

[1] Aiello, S.E. and Mays, A. (editors) (1998). The Merck Veterinary Manual. 8th Edition. Merck \& Co., Inc.

[2] Baipoledi, E. K., Nyange, J. F. C. and Hyera, J. M. K., (2002), 'A severe case of contagious ecthyma in Tswana goats', Journal of South African Veterinary Association 73(2), 8687.

[3] Bath, G. F, Janse van Rensburg, A., Pettey, K. P., Van Vuuren, M. and Kidanemariam, A., 2011, 'A literature review and investigation of staphylococcal necrotic dermatitis in sheep', Journal of the South African Veterinary Association 82(4), 227-231.

[4] Bayindir Y, Bayraktar M, Karadag N, Ozcan H, Kayabas U, Otlu B, Durmaz R, Doganay M (2011) Investigation and analysis of a human orf outbreak among people living on the same farm. New Microbiol 34:37-43.

[5] Coskun O, Gul $\mathrm{CH}$, Bilgeturk A, Besirbellioglu BA, and Eyigun, C. P. (2008) Human orf complicated with erythema multiforme. Int J Dermatol 47:1333-1334.

[6] Deane, D., McImes, C. J., Percival, A., Wood, A., Thomson, J., Lear, A., Gilray, J., Fleming, S., Mercer, A. and Haig, D., (2000). Orf virus encodes a novel secreted protein inhibitor of granulocyte-Macrophage colony-stimulating factor and interleukin-2. Journal of Virology, 74: 3: 1313 - 1320.

[7] Fauquet, C.M., Mayo, M.A., Maniloff, J., Desselberger, U. and Ball, L.A. (eds.)., 2005. Virus Taxonomy, Eighth Report of the International Committee on Taxonomy of Viruses. Elsevier/Academic Press, London, Jun 2005.

[8] Karakas, A., Turhan, V. and Kucukodaci, Z., (2010) Human orf: report of two cases. Turk Armed Forces Prev Med Bull 9:551-552 8

[9] Kitching, R. P., 2004, 'Orf', in J. A. W. Coetzer and R.C. Tustin (eds.), Infectious diseases of livestock, 2nd edn., vol. 2, pp. 1282-1286, Oxford University Press, Cape Town.

[10] Klein, J. and Tryland, M., 2005, 'Characterisation of parapoxviruses isolated from Norwegian semi-domesticated reindeer (Rangifer tarandus tarandus)', Virology 2, 79.

[11] Lederman, E.R., Green, G.M., De Groot, H.E., Dahl, P., Goldman, E., Greer, P.W. et al., 2007, 'Progressive orf virus infection in a patient with lymphoma: Successful treatment using Imiquimod', Clinical Infectious Diseases 44(11), 100103.

[12] McElroy, M.C. and Bassett, H.F., 2007, 'The development of oral lesions in lambs naturally infected with orf virus', The Veterinary Journal 174, 663-664. http:// dx.doi.org/10.1016/ j.tvj1.2006.10.024

[13] McInnes CJ, Wood AR, Thomas K, Sainsbury AW, Gurnell J, Dein J, and Nettleton PF (2006) Genomic characterization of a novel poxvirus contributing to the decline of the red squirrel (Sciurus vulgaris) in the UK. J Gen Virol 87:2115-2125

[14] Ministry of livestock development and fisheries report-Tanzania

[15] MMWR (2012) Human orf virus infection from household exposures United States, 2009-2011. MMWR Morb Mortal Wkly Rep 61:245-248

[16] Newsome, I.E. and Cross F (1934) Sore mouth in sheep transmissible to man. J Am Vet Med Assoc 84:799-802

[17] Nitsche, A., Buttner, M., Wilhelm, S., Pauli, G. and Meyer, H. (2005). Real-Time PCR Detection of Parapoxvirus DNA, 2005 DOI: $10.1373 /$ clinchem.059691

[18] Ramesh, A., Vadivoo, V. S, Babu, S. S., and Saravanabava K., (2008). Confirmatory diagnosis of contagious ecthyma by amplification of the GIF/IL-2 gene by PCR. Tamilnadu J. Veterinary \& animal sciences 4 (6) 208-210

[19] Rossiter, P. B. and Taylor, W. P., 1994, 'Peste des pestis ruminants', in J. A. W. Coetzer \& R. C. Tustin (eds.), Infectious diseases of livestock, vol. 2, pp. 758-765, Oxford University Press, Cape Town.

[20] Sambrook J. and Russell D. W. (2000).Molecular cloning: a laboratory manual. Cold Spring Harbour Laboratory Press, Plainview, New York, 6 (13): 6-19.

[21] Scagliarini, A., Dal Pozzo, F., Gallina, L., Guercio, A., Vaccari, F. and Battilani, M. et al., 2006, 'In vitro activity of 
VEGF-E produced by orf virus strains isolated from classical and severe persistent contagious ecthyma', Veterinary Microbiology 114, 142-147.

[22] Smith, G.W., Scherba, G., Constable, P.D., Hsiao, V., Behr, M.J. and Morin, D.E., 2002, 'Atypical parapoxvirus infection in sheep', Journal of Veterinary Internal Medicine 16 , 287-292. http://dx.doi.org/10.1111/j.1468-3083.2006.01496.x

[23] Steinhart, B., 2005, 'Orf in humans: Dramatic but benign (case report)', Canadian Journal of Emergency Medicine $7(6), 417$.

[24] Tamura K, Stecher G, Peterson D, Filipski A, and Kumar S (2013) MEGA6: Molecular Evolutionary Genetics Analysis version 6.0. Molecular Biology and Evolution: 30 2725-2729.

[25] Watson, P., 2004, 'Differential diagnosis of oral lesions and FMD in sheep', In Practice 26, 182-191.

[26] World Organisation for Animal Health OIE.
[27] Zhang K, Lu Zhongxin, Shang Youjun, Zheng Haixue, Jin Ye, He Jijun and Liu Xiangtao (2010). Diagnosis and phylogenetic analysis of Orf virus from goats in China: a case report Virology Journal 2010, 7:78

[28] Zheng, M., Liu, Q., Jin, N., Jiangang, G., Huang, X., Li, H. et al., (2007). 'A duplex PCR assay for simultaneous detection and differentiation of Capripoxvirus and Orf virus', Molecular and Cellular Probes 21, 276-281.

[29] Scagliarini, A., Piovesana, S., Turrini, F., Savini, F., Sithole, F. \& McCrindle, C.M., 2012, 'Orf in South Africa: Endemic but neglected', Onderstepoort Journal of Veterinary Research 79(1), Art. \#499, 8 pages. http://dx.doi.org/10.4102/ ojvr.v79i1.499

[30] Bouznach, A., Hahn, S., Stram, Y., Menasherov, S., Edery, N., Shicaht, N., Kenigswald, G. and Perl, S. 2013. Case Report: Contagious Ecthyma - Deviations in the Anatomical Appearance of Lesions in an Outbreak in Lambs in Israel. Israel Journal of Veterinary Medicine Vol. 68 (4) 